\title{
THE OMBUDSMAN: MALADMINISTRATION AND ALTERNATIVE DISPUTE RESOLUTION
}

\author{
MARY A. MARSHALL and LINDA C. REIF
}

The authors seek to highlight the office of the ombudsman, which represents a potentially powerful form of alternative dispute resolution. They first examine the "classic" ombudsman. This ombudsman is basically a neutral party who decides which side is justified in a dispute. They examine how Canadian ombudsman legislation ensures that many of the ombudsman's most important aspects are protected, such as impartiality and immunity from prosecution. They next examine the boundaries of the ombudsman's jurisdiction which, for the classic ombudsman, encompass only the administrative actions of government. The procedures common 10 most classic ombudsman offices are also outlined.

Next, some challenges to the classic ombudsman are canvassed, such as the privatization of government services. They favour a contimuing role for the ombudsman in regulating privately-delivered "public" services. Next, the article looks at different forms of the ombudsman, as adapted around the world. They provide an organizational scheme for these adaptations. Each model is analyzed, and its strengths and weaknesses assessed. The article concludes by stating the similarities found in all ombudsman models and which make the office an important form of $A D R$
Les auteurs mettent en vedette la fonction d'ombudsman, qui représente une solution de rechange particulièrement prometteuse au règlement des conflits. Ils examinent d'abord l'ombudsman "classique», partie essentiellement neutre chargée de décider qui a raison. Ils examinent comment la législation canadienne assure la protection des aspects les plus importants de cette fonction - ceux d'impartialité et d'immunité, notamment. Ils examinent ensuite le champ de compétence de l'ombudsman qui se limile, dans le cas de l'ombudsman classigue, aux actions administratives du gouvernement. Les procédures communes à la plupart des ombudsmans classiques sont également décrites.

Puis, certaines initiatives qui interpellent la fonction d'ombudsman classigue sont inventoriées - la privatisation des services publics, notamment. Les auteurs souhaitent que l'ombudsman continue à surveiller les services "publics» dispensés par le secteur privé. Les auteurs examinent ensuite différents types d'ombudsman ailleurs dans le monde, d'après un cadre organisationnel élaborés par leurs soins. Chaque modele est analysé et évalué en fonction de ses points forts et ses faiblesses. En conclusion, l'article présente les éléments communs à tous les ombudsmans, qui offrent une forme importante de règlement de différents sans recours aux tribunaux.

\section{TABLE OF CONTENTS}

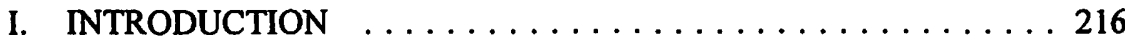

II. CLASSICAL LEGISLATIVE OMBUDSMAN $\ldots \ldots \ldots \ldots \ldots 217$

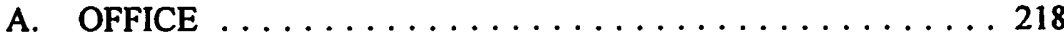

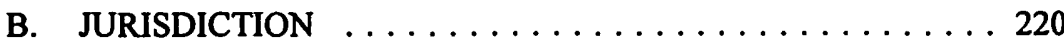

C. REPORTING AND RESOLUTION $\ldots \ldots \ldots \ldots \ldots \ldots 222$

D. TRENDS AND CHALLENGES TO THE

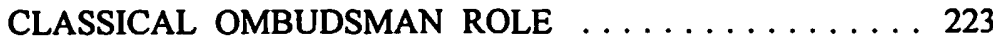

III. OTHER OMBUDSMAN MODELS $\ldots \ldots \ldots \ldots \ldots \ldots \ldots 225$
A. VARIATIONS OF THE GENERAL JURISDICTION GOVERNMENT OMBUDSMAN $\ldots \ldots .227$
B. THE SINGLE-PURPOSE OMBUDSMAN $\ldots \ldots \ldots \ldots 230$

Ms. Marshall is a partner with Cook Duke Cox, Edmonton, Canada, and is the Chair of the Special Projects Committee, International Ombudsman Institute. Professor Reif, Faculty of Law, University of Alberta, is Editor for the International Ombudsman Institute. 
C. THE HYBRID OFFICE:

OMBUDSMAN/HUMAN RIGHTS COMPLAINTS ..... 231

D. GOVERNMENT IN-HOUSE COMPLAINT

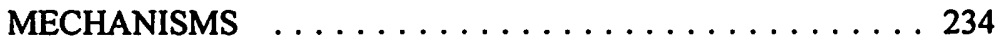

E. PRIVATE SECTOR COMPLAINT

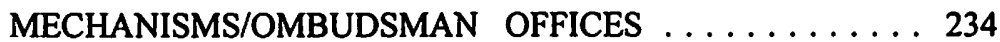

F. EMERGENCE OF THE OMBUDSMAN CONCEPT

IN THE INTERNATIONAL SYSTEM $\ldots \ldots \ldots \ldots \ldots 235$

IV. CONCLUSION

239

\section{INTRODUCTION}

Over the past couple of decades the office of the ombudsman' has played an increasingly important role in Canadian society, owing largely to the growth and complexity of government administration. Individuals today come into contact with the civil service more often than did their forebears. Health care issues, building restrictions and licensing are good examples of government involvement in everyday affairs.

Although the office of ombudsman is relatively recent, the concept has ancient origins. Examples of older forms of the office are the Swedish Justitieombudsman of 1809 and the Control Yuan of ancient China. ${ }^{2}$ Both the origin of the word "ombudsman" and the origin of the modern concept of the ombudsman are Swedish. The Swedish Justitieombudsman sparked similar offices in Finland (1919), Denmark (1953), New Zealand (1962) and the United Kingdom (1967). Today, there are ombudsman offices worldwide. Offices exist in Central and South America, Tanzania, Zambia and Papua New Guinea, among other countries.

It is appropriate that a chapter on the ombudsman be present in a volume dealing with alternative dispute resolution. An ombudsman has been described as an individual who provides non-binding arbitration between individuals and government.

The process is voluntary for the individual and mandatory for the govermment. The office is independent of government, yet it is not the individual's advocate. It acts as an impartial investigator with wide powers of investigation into matters of administration and provides accountability through reports to individual complainants, government, the legislature and the general public. ${ }^{3}$

An ombudsman provides a valuable form of alternative dispute resolution for citizengovernment disputes. The barriers of cost and delay make court proceedings an unrealistic option. Many individuals are unfamiliar with the structure of large public bureaucracies, and they experience great difficulty in approaching government directly

I Ombudsmen may be men or women. The pronouns in this article are used indiscriminately to reflect this fact. Other terms for the office include: parliamentary commissioner for administration; public complaints commissioner; and protecteur du citoyen.

2 S. Owen, "The Ombudsman: Essential Elements \& Common Challenges" in L. Reif, M. Marshall \& C. Ferris, eds., The Ombudsman: Diversity and Development (Edmonton: International Ombudsman Institute, 1993) 1 at 2. 
to resolve problems and concerns. Finally, an ombudsman may play a role in the consensual resolution of public interest disputes by identifying parties with legitimate and significant interests, developing a common set of facts, and setting out the major issues requiring resolution.

\section{CLASSICAL LEGISLATIVE OMBUDSMAN}

The arrival of the ombudsman in Canada is quite recent. The first ombudsman office in Canada was created in Alberta in 1967. All the provincial governments, except Prince Edward Island, soon set up offices. Regrettably, the office of the ombudsman in Newfoundland was discontinued in 1992 due to budgeting restraint. The legislation governing the ombudsman is remarkably similar in each province.

The characteristics and purposes of the classical ombudsman office have been outlined by the International Ombudsman Institute in its By-Laws as follows:

(i) to investigate grievances of any person or body of persons concerning any decision or recommendation made, or any act done or omitted, relating to a matter of administration, by any officer, employee or member or committee of members of any organization over which jurisdiction exists and

(ii) to investigate complaints against government or semi-government departments and agencies and

(iii) a responsibility to make recommendations resulting from investigations to organizations under jurisdiction and

(iv) to discharge the role and functions as an officer of the legislature or on behalf of the legislature in a role which is independent of the organizations over which jurisdiction is held and

(v) to report to the legislature either directly or through a Minister on the results of its operations or on any specific matter resulting from an investigation."

International Ombudsman Institute, By-Laws (Edmonton: IOI, 1978). The International Ombudsman Institute was established in 1978 and its head office is situated at the University of Alberta in Canada. It was formed for the following purposes:

(a) To promote the concept of Ombudsman and to encourage its development throughout the world.

(b) To encourage and support research and study into the office of the Ombudsman.

(c) To develop and operate educational programs for Ombudsmen, their staff, and other interested people.

(d) To collect, store, disseminate information and research data about the institution of Ombudsman.

(e) To develop and operate programs enabling an exchange of information and experience between Ombudsmen throughout the world.

(f) To provide scholarships, fellowships, grants and other types of financial support to individuals throughout the world to encourage the development of the Ombudsman concept and to encourage study and research into the institution of Ombudsman.

(g) To plan, arrange and supervise International Ombudsman Conferences.

(h) To undertake such other matters as are necessary to further the above objects. 
This article explores the nature of the classical ombudsman role, recent developments in this role and some other ombudsman models. In examining the classic legislative ombudsman, the article will first deal with the structure of the ombudsman office, his jurisdiction and, finally, methods used by the ombudsman to resolve problems. Canadian legislation will be used to illustrate aspects of a classic ombudsman model.

\section{A. OFFICE}

The ombudsman office has three main functions:

(a) to investigate complaints and allegations;

(b) to secure redress in cases where the complaint is found to be justified; and

(c) to help bring about improvements in administrative systems and procedures generally.

Impartiality and independence characterize the ombudsman office. The ombudsman is not the complainant's advocate. He looks at both sides of the case and "decides who is justified and who is not." It is essential that ombudsmen are seen to have these characteristics or they will not be able to perform properly their function as investigators. The unimpeded flow of information is also essential to their role. As an investigator, the ombudsman must be able to obtain information and make recommendations without her sources or herself fearing the consequences.

Canadian legislators have provided for the ombudsman's independence through a variety of means. One of these protections is that ombudsmen are prohibited from holding paid public office. For an ombudsman to hold office as a legislator or civil servant would give the appearance, if not the real existence, of partiality. As a legislator, it would be perceived that he was implementing a specific political agenda. As a civil servant, he would potentially be sitting in review of his own actions. Alberta deals with this concern in s. 3(1) of the Ombudsman Act, ${ }^{7}$ which prohibits the ombudsman from sitting in the Legislative Assembly or holding any office for profit other than the ombudsman office. All paid offices are prohibited, not just public ones. This measure ensures that the ombudsman devotes full attention to the position.

A further element of the ombudsman's freedom from personal bias is his appointment by the legislative rather than the executive branch of government. In Alberta, the Lieutenant Governor-in-Council appoints the ombudsman on recommendation of the Legislative Assembly. ${ }^{8}$ In Quebec, the National Assembly 
makes the appointment. Two-thirds of its members must approve of the appointment for it to be effective.

Several provisions guarantee the continued independence of the office. The ombudsman is an officer of the legislature, not the government. The legislature controls his salary and budget. ${ }^{10}$ Some provinces even pay ombudsmen on the same scale as judges." The executive has only limited powers of removing or replacing the ombudsman. $^{12}$ When the legislature is in session, the executive may remove the ombudsman on recommendation of the assembly. When it is not in session, it can only remove the ombudsman on recommendation of the Select Standing Committee of the Legislative Assembly. Such a recommendation must be confirmed by the Assembly on the resumption of session. In the provinces of Nova Scotia and New Brunswick, the courts are given the power to remove and temporarily replace the ombudsman. ${ }^{13}$

The confidentiality of the ombudsman's proceedings helps to ensure his independence as well as to facilitate cooperation throughout the investigation. The ombudsman's investigation must be held in private ${ }^{14}$ and his reports and investigation may not be made the subject of an inquiry or review, apart from a review ordered by the Legislative Assembly, its committees or another body which the Legislative Assembly authorizes. ${ }^{15}$ Neither the ombudsman nor his employees may be called to give evidence in court or to provide documents. ${ }^{16}$ They are immune from prosecution, including defamation, for anything they say or do in good faith while exercising their duties. ${ }^{17}$

The ombudsman has complete control over the conduct and procedure of the investigation, including the calling of any person or viewing of any information she sees fit. She has the right to require information or documents ${ }^{18}$ and may examine any relevant person on oath. ${ }^{19}$ Persons must divulge the information requested of them. ${ }^{20}$ They are protected against the use of their evidence in subsequent proceedings. Perjury is the only partial exception to this rule. ${ }^{21}$ The ombudsman and her department must

9 Public Protector Act, R.S.Q. 1977, c. P-32, s. 1.

$10 \quad$ O.A., supra note 7, s. $8,9,10$.

1 British Columbia and New Brunswick pay Ombudsmen on the same level as judges: Ombudsman $A c t$, R.S.B.C. 1979, c. 306, s. 4(1); Ombudsman Act, R.S.N.B. 1973, c. O-5, s. 2(4). Benefits are usually tied to that of an equivalent-level civil servant. See $O . A$., ibid., s. 8(2). O.A., ibid., ss. 6-7.

Ibid., s. 6(1). An Act to Establish the Office of the Ombudsman, R.S.N.S. 1989, c. 327, s. 5; New Brunswick Ombudsman Act, supra note 11, s. 3(2)-(4).

$O . A$., ibid., s. 16. Only the British Columbia Ombudsman Act allows public hearings and only in "special circumstances," supra note 11, s. 9(5).

O.A., ibid., s. 22.

Ibid., s. 24(2)(3). The British Columbia equivalent to this section (s. 9(4) of the British Columbia Act, supra note 11) was considered in Levey v. Friedman (1985), 60 B.C.L.R. 101 (S.C.), where the court held that this section must be given a wide interpretation (at 103).

O.A., ibid., s. 24.

Ibid., s. 17(1)-(2).

Ibid., s. 17(3).

Ibid., s. 17(4)-(5).

Ibid., s. 17(6)-(8). Also see generally, Millett v. City of St. John (1986), 70 N.B.R. (2d) 233 (Q.B.). 
maintain secrecy with respect to all matters unless they ought to be disclosed in the final report. ${ }^{22}$

Independence is an essential element of the ombudsman's role. In order to do her job properly she must be and must be seen to be independent from the administration she reviews.

\section{B. JURISDICTION}

The question of whether the ombudsman has "jurisdiction" to investigate a complaint may refer to one or more of the following questions:

(1) Does the complainant have status to complain to the ombudsman?

(2) Should the ombudsman exercise her discretion not to investigate?

(3) Is this aspect of governmental action subject to investigation?; and

(4) Is this public body subject to investigation?

The ombudsman may investigate on the complaint of any individual or on her own initiative. ${ }^{23}$ She may also investigate a matter that a Legislative Assembly committee or a Minister refers to her. ${ }^{24}$

An ombudsman also has wide discretion not to investigate. The decision not to investigate is a matter of discretion, which is not reviewable. One example of this discretion is that the ombudsman may refuse to investigate when a matter was not brought to him until one year or later after the issue arose. ${ }^{25} \mathrm{He}$ may also refuse to investigate when he deems a matter frivolous, the complainant has suffered no prejudice, or other adequate remedies exist. ${ }^{26}$ Where an ombudsman chooses not to

O.A., ibid., s. 19.

Ibid., s. $11(2)$.

O.A., ibid., s. 11(4)-(5).

Ibid., s. 14(2)(a).

Section 14 of the $O . A$., ibid. provides when an ombudsman's discretion may be exercised. It states:

14(1) If in the course of the investigation of any complaint it appears to the Ombudsman

(a) that under the law or existing administrative practice there is an adequate remedy, other than the right to petition the Legislature, for the complainant, whether or not he has availed himself of it, or

(b) that, having regard to all the circumstances of the case, any further investigation is unnecessary,

he may in his discretion refuse to investigate the matter further.

(2) The Ombudsman may, in his discretion, refuse to investigate or cease to investigate any complaint

(a) if it relates to any decision, recommendation, act or omission of which the complainant has had knowledge for more than 12 months before the complaint is received by the Ombudsman, or

(b) if in his opinion,

(i) the subject matter of the complaint is trivial,

(ii) the complaint is frivolous or vexatious or is not made in good faith, or

(iii) the complainant has not a sufficient personal interest in the subject matter of the complaint. 
investigate, he must inform the complainant of his decision and may give reasons for this decision. ${ }^{27}$

The scope of classical ombudsman jurisdiction encompasses administrative but not legislative actions. Owen describes the distinction between administrative and legislative policies as follows:

Developing legislation is a political task which typically involves debating the relative merits of differing social and economic policies. In this, an ombudsman has no business.... Administrative policy development is very different. It involves the translation and application of broad legislative policy to individual situations. It describes method, not purpose, and it requires the exercise of discretion by public servants which creates the potential for arbitrariness. These are fundamentally the business of an ombudsman. ${ }^{23}$

The ombudsman cannot review the legislative or judicial branches of government. ${ }^{29}$ Quasi-judicial boards or tribunals, however, are not immune from ombudsman scrutiny. ${ }^{30}$

The courts have interpreted the ombudsman's jurisdiction very widely. In the case of Re British Columbia Development Corp. and Friedmann, ${ }^{31}$ the issue of whether the ombudsman could investigate a Crown agency's breach of contract was in question. The Supreme Court of Canada stated:

The words "administration" or "administrative" everywhere qualify the Ombudsman's jurisdiction. In the Act under consideration, and in the Ombudsman Acts of Alberta, Saskatchewan, Manitoba and Newfoundland, the relevant phrase is "a matter of administration"... There is nothing in the words "administration" or "administrative" which excludes the proprietary or business decisions of governmental organizations. On the contrary, the words are fully broad enough to encompass all conduct engaged in by a governmental authority in furtherance of governmental policy - business or otherwise.

In my view, the phrase "a matter of administration" encompasses everything done by governmental authorities in the implementation of govemment policy. I would exclude only the activities of the Legislature and the courts from the Ombudsman's scrutiny. ${ }^{32}$

$27 \quad$ Ibid., s. 14(3).

23. Owen, supra note 2 at 7.

29 See Re British Columbia Development Corporation and Friedmann (1984), 14 D.L.R. (4th) 129 (S.C.C.).

30 See Re Alberta Ombudsman Act (1970), 10 D.L.R. (3d) 47 (Alta. S.C.T.D.); Re Ombudsman of Ontario and Health Disciplines Board of Ontario (1979), 104 D.L.R. (3d) 597 (Ont. C.A.); $R e$ Ombudsman of Ontario and Ontario Labour Relations Board (1986), 58 O.R. (2d) 225 (C.A.). 
The ombudsman may not investigate a decision before the right of appeal has been exhausted in respect of that matter or any decision by a solicitor for the Crown. ${ }^{33}$ If in doubt, she may apply to the courts for a determination of her jurisdiction. ${ }^{34}$

In Alberta, the ombudsman may investigate any act, decision or recommendation made in relation to a matter of administration when done by a government department, agency or government employee acting in a government role. ${ }^{35}$ The activities of some Crown corporations may fall within the ambit of some ombudsman Acts depending on the degree of government control over that agency.

\section{REPORTING AND RESOLUTION}

Before investigating a complaint, the ombudsman must inform the deputy minister or administrative head of any department or agency of her intention to investigate. ${ }^{36}$ She must also inform such individual if she finds evidence of a breach of duty or misconduct by an employee of that department. ${ }^{37}$ If the minister of that department requests it, the ombudsman shall consult the minister at the conclusion of the investigation but before making a report. ${ }^{38}$

In general, the role of the ombudsman is to make recommendations and to work through persuasion. He does not have power to force compliance with his recommendations but operates instead through discussion with the government.

O.A., supra note 7, s. 12(1). The Saskatchewan and Manitoba legislation both allow resort to the ombudsman notwithstanding an appeal where the ombudsman determines such appeal is not practical in the circumstances. See the Ombudsman Act, R.S.M. 1987, c. O-45, s. 18(d) and the Ombudsman Act, R.S.S. 1978, c. O-4, s. 15(1). See also Re Ombudsman of Ontario and Health Disciplines Board of Ontario, supra note 30.

O.A., ibid., s. 12(2).

"Agency" and "department" are defined in the Financial Administration Act, R.S.A. 1980, c. F-9 as follows:

1(c) "department" means

(i) a department of the Government or of the public service of Alberta established under the Government Organization Act,

(ii) a part of the public service of Alberta that is not part of a department referred to in subclause (i) and that is designated as a department by the Lieutenant Governor in Council for the purposes of this Act, or

(iii) any other part of the public service of Alberta,

but does not include

(iv) the Legislative Assembly Office,

(v) the Office of the Auditor General,

(vi) the Office of the Ombudsman,

(vii) the Office of the Chief Electoral Officer, and

(viii) the Office of the Ethics Commissioner;

(1) "Provincial agency" means a Provincial corporation or a Provincial committee... O.A., supra note $7, \mathrm{~s} .15(1)$.

Ibid., s. 15(4).

Ibid., s. 15(3). 
An ombudsman may be able to offer informal mediation services throughout the investigation.

In keeping with the general principle that it is the proper role of an ombudsman office to strive for the mutually acceptable resolution of a problem rather than necessarily a finding of fault or absence of it, the office should attempt to provide informal mediation services wherever such an approach may be productive. This approach not only tends to result in greater satisfaction among all parties, but frequently provides a more rapid resolution than a full investigation oriented towards a finding of right or wrong. ${ }^{39}$

After the investigation, the ombudsman reports the findings and recommendations to the appropriate minister and department. Only if the ministry does not take action within a reasonable time does the ombudsman send a copy of the report to the Lieutenant-Governor and thereafter to the Legislative Assembly. ${ }^{40}$ The ombudsman is required to inform the complainant of the result of his investigation. ${ }^{41}$ As well, an ombudsman is required to report on a yearly basis to the Legislative Assembly. In addition, where he deems it appropriate, he may make a public report on some matter within his jurisdiction. ${ }^{42}$ A department, agency or individual who is criticized by a public report or a report to the Legislature must be given an opportunity to be heard before this report is made. ${ }^{43}$

\section{TRENDS AND CHALLENGES TO THE CLASSICAL OMBUDSMAN ROLE}

In many jurisdictions, commercialization and devolution are slowly eroding the ombudsman's ability to investigate the administration of public services. Commercialization may take one of the following three forms: privatization or transferring government ownership of a Crown corporation to private ownership; contracting out for services; and private sector provision of public services.

Private jails are an example of commercialization. Private jails are being considered in Alberta and New Brunswick. Pilot projects are already under way in the United Kingdom. In order to protect prisoners in the U.K., a specialized prison ombudsman service is being developed.

Devolution involves the transfer of greater control and decision making to local/ regional authorities for some or all of the planning, funding, management, revenue

Owen, supra note 2 at 5 . The extent of the informal mediation services offered by the ombudsman varies from province to province.

O.A., supra note $7, \mathrm{~s} .20$. Comments made by the department or agency regarding the report must be included with the ombudsman's report to the Lieutenant Govemor or Legislative Assembly.

Ibid., s. 21. In most provinces including Alberta, this obligation only exists when the complaint is supported by the investigation. However, in British Columbia and Quebec, the ombudsman must inform the complainant if the results of the investigation are negative: British Columbia Act, supra note 11, s. 21; Quebec Act, supra note 9, s. 29.

O.A., ibid., s. 27.

Ibid, s. 27(3). 
generation and delivery functions. "The degree of devolution lies along a continuum between full central control and full local/regional control. ${ }^{.44}$

Health care is an area that reflects the trend towards devolution of control and decision-making. For example, in the United Kingdom, New Zealand and a number of the Canadian provinces (Alberta, Saskatchewan and New Brunswick), regional health authorities have recently assumed many of the planning, funding, management and delivery functions for health care services which were formerly subject to central control.

There are two strong arguments for maintaining the ombudsman's supervisory role over the administration of public services as their delivery is privatized, or control and decision making is devolved to local and regional bodies. The first argument is based on the nature of public services. Owen notes as follows:

Public services, whether delivered by a public bureaucracy or a private firm, must meet set standards.... To the extent that private services are offered in a perfect market, the existence of real alternatives holds the competitors accountable for meeting the expectations of consumers. Public services are never subject to this market control, even if they are delivered privately. While privately owned firms might bid competitively for the right to provide a public service, what they acquire is non-competitive market power during the term of their service contract. ${ }^{\text {is }}$

By maintaining the ombudsman's involvement, government ensures that private sector firms and regional bodies are accountable to individual members of the public for quality.

Second, since support for devolution is part of the contemporary political culture, it is valued in itself, regardless of whether formal evaluations are done. At present, there is no theory of how, why and when to devolve. The results of devolution are not yet known as evaluations have not been done; however, the experience to date does not support the achievements of the presumed benefits of devolution. ${ }^{46}$ Further, as authority is devolved to regional bodies, it is often unclear to individual members of the public as to who has accountability for the provision of public services. Maintaining the ombudsman role would improve and facilitate accountability to individual members of the public.

Premier's Council on Health, Well-being and Social Justice, A Framework for Evaluating Devolution (Toronto: Queen's Printer for Ontario, 1994) at A-1.

$45 \quad$ Owen, supra note 2 at 8.

46 See e.g. A. Dunsire, K. Hartley \& D. Parker, "Organizational status and performance: Summary of the findings" (1991) 69 Public Administration, 21-40; J.I. Elstead, "Health Services and Decentralized Government: The Case of Primary Health Services in Norway" (1990) 20 International Journal of Health Services 545; and R. Gosselin, "Decentralization/regionalization in health care: The Quebec experience" (1984) 9:1 Health Care Management Rev. 7. 


\section{OTHER OMBUDSMAN MODELS}

The ombudsman institution has been adopted and adapted in a. variety of ways within a growing number of countries around the world, primarily within the past two to three decades. ${ }^{47}$ At present, there are over one hundred government ombudsman offices, almost sixty of which are at the national level, together with many more variants on the ombudsman model..$^{48}$ Such developments, within and across nations, are due to factors unique to the particular countries in question. However, several factors that have contributed to this movement and which are common to many of these countries can be highlighted. These are: (1) the increase in bureaucracy, and its attendant problems, in governments and institutions (notwithstanding the privatization and down-sizing movements that have been instituted in both the public and private sectors in the past fifteen years); and (2) the democratic development of countries in Latin America, Asia, Africa and Central and Eastern Europe, occurring mainly since the 1980s and increasing in the post-Cold War period. ${ }^{49}$

Each of the variations of the ombudsman model discussed below are mechanisms that attempt to settle disputes between governments (or institutions) and members of the public (or their clients) over poor government administration or treatment of members of the public. Each model can be criticized because each changes or omits one or more components of the classic legislative ombudsman model discussed earlier. However, each variant of the traditional model is an attempt to meet the particular problems encountered by members of the public (or clients) in their interaction with the bureaucracy of the state (or the institution). These concerns range from the usual cases of bureaucratic and administrative unfairness to instances of corruption and human rights infringements committed by state agents. Thus, although each variation can be critiqued according the classical ombudsman model, other political, legal, socioeconomic and cultural aspects of the particular national environment surrounding the office must also be taken into account when exploring the mandate and effectiveness of each variation on the ombudsman theme.

Objectives for the creation of contemporary ombudsman variants include the following: greater accountability of government to the people, the promotion of democratic development and good governance, a mechanism to protect human rights

47 See generally G.E. Caiden, ed., International Handbook of the Ombudsman: Evolution and Present Function (Westport, Connecticut: Greenwood Press, 1983); Reif, Marshall \& Ferris, eds., supra note 2; L. Reif, ed., The Ombudsman Concept (Edmonton: International Ombudsman Institute, 1995).

4 See International Ombudsman Institute, Directory of Ombudsman Offices (Edmonton: International Ombudsman Institute, March 1995). See also D. Jacoby, "The Future of the Ombudsman" in Reif, ed., ibid. at 211.

49 For descriptive views of and critical approaches to the democratization movement see e.g. S.P. Huntington, The Third Wave: Democratization in the Late Twentieth Century Norman: University of Oklahoma Press, 1991); G. J. Schmitz \& D. Gillies, The Challenge of Democratic Development: Sustaining Democratization in Developing Societies (Ottawa: The North-South Institute, 1992); L. Diamond \& M.F. Plattner, eds., The Global Resurgence of Democracy (Baltimore: Johns Hopkins University Press, 1993); L. Diamond, ed., Political Culture and Democracy in Developing Countries (Boulder, Lynne Rienner Pub., Inc., 1994). 
of individuals against government infringement thereof, a means of attacking corruption of government officials, and a general dispute resolution system for the individuals with complaints against government administration who cannot access the formal judicial system for socio-economic reasons or because the complaint is not a violation of existing domestic law.

Although the ombudsman ${ }^{50}$ model has been adapted in haphazard fashion, the variations can be organized broadly, as follows: ${ }^{51}$

(1) Government Ombudsman Offices With General Jurisdiction Over Administrative Conduct:

(a) created by national, regional, provincial/state or by municipal government;

(b) established by the legislative branch of government or by the executive power (some may place the "executive ombudsman" in a separate category);

(c) related to the above, established by constitutional provision, legislation or by executive decree;

(2) Government Ombudsman Offices With Limited Subject-Matter Jurisdiction (the "Single-Purpose" Ombudsman):

- $\quad$ same (a) to (c) as above in (1);

(3) Establishment of Hybrid Ombudsman/Human Rights Complaint Offices by Government:

same (a) to (c) as above in (1), although they are established mainly at the national level or at combined national/sub-national levels in federal states;

(4) In-house Complaints Mechanisms Created By Government Departments/Agencies or State-owned Corporations;

The term "Ombudsman" is used in many countries that have adapted the office from its Scandinavian toots (e.g. provinces of Canada, New Zealand). Other English language synonyms are: "Parliamentary Commissioner for Administrative Investigations" (e.g. Queensland, Western Australia); "Commissioner for Administrative Complaints" (Hong Kong); and "Parliamentary Commissioner for Administration" (e.g. United Kingdom, Sri Lanka). In French-speaking jurisdictions see e.g.: Médiateur (e.g. France, Senegal, Mauritania); Protecteur du Citoyen (Québec); Défenseur du Peuple (Madagascar). In Spanish-speaking countries see e.g.: Defensor del Pueblo (e.g. Argentina, Spain); Defensor de los Habitantes (Costa Rica). In India, the office is called Lok Ayukta.

s1 We have followed in part the categorization used by D. Jacoby, supra note 48 at $211-14$, with the exception that Jacoby places the executive ombudsman in a separate category. 
(5) In-House Complaints Mechanisms Created by Private Sector Institutions/Corporations; and

(6) Creation of Ombudsman or In-house Complaints Mechanisms at the International or Supranational Level of Governance.

The classic ombudsman model - the general-service government ombudsman appointed by the legislative branch - has been explored in detail in Part II. The variations of the ombudsman institution will be described in more detail below.

\section{A. VARIATIONS OF THE GENERAL JURISDICTION GOVERNMENT OMBUDSMAN}

\section{The Provincial/State/Regional Ombudsman}

The general-service government ombudsman is found primarily at the national and/or the subunit level in federal states (i.e. at the provincial, state, etc. level), with jurisdiction over the administrative conduct of the level of government concerned. Canada, for example, has no general jurisdiction national ombudsman but does have ombudsman offices in eight provinces. ${ }^{52}$ Other countries - such as Australia and Argentina - have ombudsman both at the federal and provincial/state levels.

A number of other countries have ombudsman offices at the regional level. These offices are commonly found in Europe and generally correspond to politico-legal and geographic divisions in the particular country. For example, Italy has fourteen regional offices. ${ }^{53}$ Spain has a national ombudsman institution (Defensor del Pueblo) and there are offices for Andalusia, the Canary Islands, Valenciana, Catalonia (Sindic de Greuges de Catalunya) and the Basque region (Ararteko Pais VascolOmbudsman du Pays Basque). ${ }^{54}$ Austria, France, Germany and Switzerland also have limited numbers of regional offices. ${ }^{55}$

In Belgium there is a unique form of "regional" ombudsman, based on language and cultural ties - the Ombudsman for the Flemish Community (De ombudsman van de Vlaamse Gemeenschap). ${ }^{56}$ The Flemish Community Ombudsman commenced operations on January 1, 1993. Belgium is a federal state and, since 1970, it has been

s2 British Columbia, Alberta, Saskatchewan, Manitoba, Ontario, Québec, Nova Scotia and New Brunswick. The territorial governments have been exploring the idea of ombudsman offices and the Yukon has passed Ombudsman legislation. But see the federal offices that can be considered specialty ombudsman institutions, infra.

Il Difensore Civico: Basilicata, Campania, Emilia-Romagna, Fruili Venezia Giulia, Lazio, Liguria, Lombardei, Marche, Piemonte, Sardegna, Toscana, and Umbria regions; Bolzano and Trento provinces. International Ombudsman Institute, supra note 48 at 16-17. Ibid. at 26-27.

ss See M. Oosting, "Regional Report: Europe" in Reif, ed., The Ombudsman Concept, supra note 47 at 47.

36 See J. Goorden, "The Ombudsman Service in Flanders" (copy on file with the International Ombudsman Institute); International Ombudsman Institute, Ombudsman Office Profiles (forthcoming). 
regulated by five levels of government: the federal, provincial and municipal governments, the regions and the communities. ${ }^{57}$ Whereas there are three regions based on economic ties which also correspond to territorial areas (the Flemish region, the region of Brussels and the Walloon region), there are three communities based on language and cultural groupings: the Flemish community, the French community and the German-speaking community. ${ }^{58}$ Each community has a council and executive branch.

The Government of Flanders oversees the administration of the Flemish community through the Ministry of the Flemish Community. ${ }^{59}$ The Government of Flanders appoints the Flemish Community Ombudsman, making it an executive ombudsman institution, and the office falls under the coordination department of the Ministry of the Flemish Community. ${ }^{60}$ The Flemish Community Ombudsman is empowered to: examine and investigate complaints against services and officials of the Ministry of the Flemish Community; provide information and refer persons on to the appropriate government service when the complaint is not jurisdictional; and function as an appeal authority when public access to administrative documents is refused. ${ }^{61}$ Following the standard format, the recommendations of the ombudsman are not binding and he reports annually to the Flemish government. ${ }^{62}$

\section{The Municipal Ombudsman}

Occasionally, general-service ombudsman offices are also granted jurisdiction over municipal governments (e.g. the provincial Ombudsman of British Columbia). ${ }^{63}$ However, a growing number of municipalities or local governments have instituted ombudsman offices on their own initiative. ${ }^{64}$ For example, in Canada there is the Winnipeg ombudsman office and in the United States, municipalities such as Portland, Detroit and Anchorage have municipal ombudsman offices. ${ }^{65}$ There are also some municipal ombudsman offices in Argentina and Brazil. ${ }^{66}$ In France, Paris has a Médiateur and there are municipal ombudsman offices in countries such as Israel, the Netherlands, Belgium and Switzerland. ${ }^{67}$

The municipal ombudsman may be an executive ombudsman appointment, as discussed further below. However, there are legislative ombudsman offices at the

$37 \quad$ lbid.

s8 Ibid.

s9 Ibid.

so Ibid. See infra section 3 on the executive ombudsman variant.

61 Ibid.

$62 \quad$ Ibid.

The B.C. Ombudsman's jurisdiction was extended to municipalities in 1995.

M. Mills, "Municipal Government Ombudsman" in Reif, ed., supra note 47, 111 at 111; M.D. Farrell-Donaldson, "Will the Real Ombudsman Come Forward?" in Reif, Marshall \& Ferris, eds., supra note 2 at 65 . 
municipal level, i.e. appointed by the "legislative" branch of municipal government, such as those for the cities of Detroit and Anchorage. ${ }^{68}$

\section{The Executive Ombudsman}

To reemphasize the point, the classic ombudsman is appointed by the legislative branch and is given considerable independence from the executive arm in matters such as appointment, dismissal and budgetary allocation. Such independence enables the ombudsman to investigate and make recommendations relatively free of control or influence by the executive branch.

However, in a number of countries, the ombudsman institution has been established as an "executive ombudsman" institution. In these countries, the executive head of government appoints the ombudsman. The executive power in turn may or may not be democratically elected. On the local plane, the office of the municipal ombudsman may be an executive ombudsman variant.

Examples of executive ombudsman offices illustrate their heterogeneity. In Hong Kong, the Commissioner for Administrative Complaints is appointed by and reports to the Governor. ${ }^{69}$ In Africa, most of the offices are of the executive ombudsman variety. ${ }^{70}$ Looking at the municipal ombudsman model, the City of Portland Ombudsman is an executive ombudsman, appointed by the Mayor, although the municipality has a Commission form of government whereby the Council members (including the Mayor) act in both executive and legislative capacities."

The executive ombudsman model has drawn considerable criticism. ${ }^{72}$ The main critique of such an office is that it lacks any real independence from the institution that it is authorized to monitor, with the result that the independence of action of the ombudsman will be compromised. It is argued that either being a political appointment or fear of reprisal by the executive will dull the ability of the ombudsman to investigate, criticize and recommend change in administrative conduct to the government.

On the other hand, it is argued that the executive ombudsman can and does work effectively in some countries, depending on the particular legal and political

(is Farrell-Donaldson, supra note 64 at 65 ; Mills, supra note 64 at 112-113.

69 See IOI, supra note 56.

to F.N. Mumba, "Regional Report: Africa" in Reif, ed., supra note 47, 89 at 90-91. E.g. Tanzania (Permanent Commission of Enquiry), see M. G. J. Kimweri, "The Effectiveness of an Executive Ombudsman" in Reif, Marshall \& Ferris, eds., supra note 2 at 37. But see the new Public Protector (ombudsman) in the interim Constitution of South Africa, c. 8, ss. 110-114, who is appointed by the President after his/her nomination by the Legislature (D. Basson, South Africa's Interim Constitution: Text and Notes (Ndabeni, Cape: Juta \& Co., Ltd., 1994)).

" Mills, supra note 64 at 112-13. In contrast, the Anchorage Ombudsman is a classic legislative ombudsman, ibid. at 113-14.

32 See e.g. R. Gregory, "Building an Ombudsman Scheme: Statutory Provisions and Operating Practices" (1994) 12 The Ombudsman Journal 83 at $85-89$ for a discussion of the arguments for and against the executive ombudsman. 
environment of the nation. ${ }^{73}$ The municipal executive ombudsman is also seen to be a realistic and effective model, given the particular structures of municipal governments and the pressing need to provide a conduit between city governments and their constituents. ${ }^{74}$ Michael Mills, the Ombudsman of Portland, has canvassed both the advantages of and the problems engendered by the executive municipal ombudsman model, and recognizes that:

The executive ombudsman, being accountable to the government's chief executive officer, is not in fact independent of the government. While the individual can operate in an impartial manner, they may not be considered by the public as being so when they serve at the pleasure of one elected executive. The degree to which the individual imparts impartiality to the citizens they serve is largely dependent upon the values of the elected official to whom they are accountable. ${ }^{\text {s }}$

This statement is applicable to all executive ombudsman institutions. It has special meaning in those countries where the executive is not elected through democratic mechanisms. In the latter situation, the status and effectiveness of an executive ombudsman institution has to be questioned closely.

\section{B. THE SINGLE-PURPOSE OMBUDSMAN}

Governments around the world have also established a variety of "single-purpose" ombudsman, otherwise known as the "special mandate" or "specialty" ombudsman, i.e. an ombudsman with jurisdiction over a particular or specialized subject-matter only. Specialty ombudsman offices exist in diverse areas, including health services, the armed services, the police, correctional services, access to information, protection of children and consumer protection. It is also possible to classify the municipal ombudsman as a form of specialty ombudsman. ${ }^{76}$ Some of these offices move away from the traditional model in their method of appointment and the types of functions that they undertake. Some single-purpose offices may not be "complaint-driven"; they may have decisionmaking powers, and they may have additional roles such as educating the public. ${ }^{77}$ As John Robertson indicates, single-purpose offices "have to be continually vigilant to avoid organizational capture arising from their close association with the special public and the organization subject to jurisdiction." ${ }^{18}$ They are able to develop considerable expertise in specialized areas.

For example, in the United Kingdom, the Parliamentary Commissioner for Administration wears a second hat as the Health Service Commissioner. ${ }^{79}$ In Canada,

E.g. Kimweri, supra note 70; Gregory, ibid.

Mills, supra note 64 at $114-16$.

Ibid. at 114.

See Jacoby, supra note 48 at 212.

J. Robertson, "The Ombudsman - World Trends" in Reif, ed., supra note 47, 3 at 5.

Ibid.

The Health Service Commissioner has the authority to investigate complaints alleging maladministration against National Health Service Authorities and Trusts. 
although there is no national ombudsman institution ${ }^{80}$ there are single-purpose offices at the federal level which can be conceptualized as attenuated ombudsman-like institutions. $^{81}$

Norway has four specialty ombudsman offices, in addition to the national ombudsman..$^{82}$ One of these offices, the Commissioner for Children (Barneombudet), has a mandate that is broader than that of the traditional model because the Commissioner's jurisdiction includes promoting the interests and rights of children in both the public and private sectors, ensuring that legislation concerning the protection of children is observed, educating public and private sectors on children's rights and proposing measures to promote the interests of children. ${ }^{83}$

\section{THE HYBRID OFFICE: OMBUDSMAN/HUMAN RIGHTS COMPLAINTS}

One aspect of the democratization and democratic consolidation of a number of countries in Latin America, Central and Eastern Europe, Africa and Asia during the past two decades is the desire of new democratic governments to reform their methods of governance and improve their accountability to the public.

There are a variety of concrete developments in various consolidating democracies attempting to improve governance. Measures taken include strengthening the separation of powers, reforming the judicial branch, improving the government's observance of human rights, increasing the accountability of the administrative arm of government, and attempting to reduce corruption of government officials. One particular development taken by an increasing number of these new democracies is the establishment of an ombudsman office often combined with a human rights complaint mandate so that, as such, they can be called hybrid offices. ${ }^{84}$ Some offices have additional powers, e.g. in Papua New Guinea the ombudsman office can investigate corruption in office. ${ }^{85}$ Each office is slightly different from the next, with some closer to the classic ombudsman model and others placing more emphasis on the human rights element. It must also be noted that all ombudsman offices throughout the world

Although there have been various proposals for such an institution. See e.g. S. Owen, "Proposal for a Canadian Federal Ombudsman Office" (1992) 10 The Ombudsman Joumal 5.

Commissioner of Official Languages, Privacy Commissioner, Information Commissioner, Federal Correctional Investigator, R.C.M.P. External Review Committee, Police Complaints Commissioner. See also some counterparts at the provincial/territorial level, e.g. the Language Commissioner of the Northwest Territories: International Ombudsman Institute, supra note $\mathbf{4 8}$ at 36.

They cover the areas of children, equal status for women, consumer affairs and military services. International Ombudsman Institute, ibid. at 39.

Bs See G.B. Melton, "Lessons From Norway: The Children's Ombudsman as a Voice for Children" (1991) 23 Case W. Res. J. Int'l Law 197; M.G. Flekkøy, "Working for the Rights of Children: The Experience of The Norwegian Ombudsman for Children" (1990) 1 UNICEF Innocenti Essays 1.

84 See L.C. Reif, "The Promotion of International Human Rights Law by the Office of the Ombudsman" in Reif, Marshall \& Ferris, eds., supra note 2 at 87; L. Reif, "International Human Rights Law and the Ombudsman Office" in Reif, ed., supra note 47 at 175.

Established in 1975, see C. Maino, "Investigating Corruption in Institutions: The Legislative Mandate" in Reif, Marshall \& Ferris, eds., ibid. at 123; C. Maino, "Ethical Considerations: The Leadership Code of Papua New Guinea" in Reif, ed., ibid. at 53. 
occasionally have to deal with human rights aspects within the scope of jurisdictional complaints of maladministration when there is not some other human rights complaint body within the same territory that could otherwise take the complaint. ${ }^{86}$

Although the ombudsman element of a hybrid office typically remains close or identical to the classic model, the human rights complaint element often is not identical to the human rights commission model found, for example, in some Commonwealth countries. ${ }^{87}$ These hybrid offices usually only have jurisdiction over human rights complaints against government officials/agents. The human rights protected by these hybrid offices are broad in scope, covering an array of civil, political, economic, social and cultural rights. These countries often have become contracting parties to a number of the international human rights treaties which uphold a full range of human rights norms, with the result that these offices can act as domestic mechanisms for the implementation of the international human rights obligations of the state. ${ }^{88}$

Some Central and Eastern Europe states have seen the establishment of both classical and hybrid offices since the collapse of the Soviet Union. Thus, the Commissioner for the Protection of Civil Rights of Poland which commenced operation in 1988 has a mandate which is closer to that of the classic ombudsman model, but which also involves human rights issues. ${ }^{89}$ Other European countries where hybrid or classical forms of the office have been established recently include Slovenia (Human Rights Ombudsman), Lithuania and Hungary. ${ }^{90}$ The establishment of an ombudsman office is being considered or implemented in countries such as Bulgaria, the Czech Republic, Estonia, Latvia, Macedonia, Romania and the Slovak Republic.9 ${ }^{91}$ The 1993 Constitution of the Russian Federation established the office of Commissioner of Human Rights to be appointed by the State Duma; however, the legislative support necessary to stipulate the powers and protection of the office was not created at the same time - with the result that Sergei Kovalev, the first appointed Commissioner, was easily removed from office by the State Duma in March $1995 .^{92}$

Latin America has seen the same democratization phenomenon over a slightly longer period, primarily since the beginning of the 1980s. A number of countries in Latin

Reif, "The Promotion of International Human Rights Law by the Office of the Ombudsman," supra note 84 at 89; M. Oosting, "The National Ombudsman of the Netherlands and Human Rights" (1994) 12 The Ombudsman Joumal 1; D. Jacoby, supra note 48 at 225.

87

83 Reif, "International Human Rights Law and the Ombudsman Office," supra note 84 at 176.

Ibid. at 175-77.

E. Letowska, "The Polish Ombudsman (The Commissioner for the Protection of Civil Rights)" (1990) 39 Int'l \& Comp. L.Q. 206; E. Letowska, "The Ombudsman and Basic Rights" (Winter 1995) 4 East Eur. Constitutional Rev. 63.

See M. Oosting, supra note 55 at 49-50.

Ibid. at 50-51.

Lawyers Committee for Human Rights, The Price of Independence: The Office of Ombudsman and Human Rights in the Russian Federation (March 1995); to be rep. in (1995) 13 The Ombudsman Journal (forthcoming). A Presidential decree permitted Kovalev to operate in the absence of legislation. The work of Kovalev in investigating and reporting on the human rights violations in Chechnya by Russian government forces led to his removal. 
America have also established classic ombudsman or hybrid ombudsman/human rights complaint mechanisms. ${ }^{93}$

Most Latin American offices have been formed over the past decade. They include the following: the Defensor del Pueblo offices at the provincial and the national level in Argentina; the Guatemalan Procurador de los Derechos Humanos; the Defensor de los Habitantes of Costa Rica; Mexico's Comisión Nacional de Derechos Humanos (National Commission of Human Rights); the Defensor del Pueblo of Colombia; and El Salvador's Procuraduría para la defensa de los Derechos Humanos, created as one element of the Chapultepec Peace Accords of 1992, negotiated under the auspices of the United Nations. ${ }^{94}$ Most of these offices were established by constitutional provision, although each office differs in the extent to which it diverges from the traditional ombudsman role and places more emphasis on the human rights protection mandate.

In its new 1994 Constitution, Argentina established an ombudsman office with additional jurisdiction over human rights complaints against government. Article 86 of the 1994 Constitution of the Republic of Argentina established the office of Defensor del Pueblo (Defender of the People) as:

an independent organ created within the realm of the National Congress, which operates with full functional autonomy, without taking instructions from any authority. Its mission is to defend and to protect human rights and other rights, guarantees and interests guarded by this Constitution and by laws regarding deeds, acts, and omissions of the Administration; and control over the exercise of public administrative functions."s

The Defensor is appointed by the National Congress and can be removed from office only by Congress, through a special majority vote in each Chamber. ${ }^{96}$

The ombudsman and hybrid offices in democratizing countries can be subjected to deeper analysis. The offices are considered by some commentators to be an important element of governance in Latin America, given the human rights and government administration records of the region. ${ }^{97}$ As noted above, the office can serve as a domestic mechanism for the implementation of international and domestic human rights obligations of the state concerned. It also serves as a means for the alternative

See N.R. Nicotra, "Regional Report: Latin America and Caribbean" in Reif, ed., supra note 47 at 95; Reif, "The Promotion of International Human Rights Law by the Office of the Ombudsman," supra note 84 at 105-11.

Ibid. See also E. Torres-Rivas and M. González-Suárez, Obstacles and Hopes: Perspectives for Democratic Development in El Salvador (San José: International Centre for Human Rights and Democratic Development, 1994).

Constitucion de la Nacion Argentina (23 August 1994), c. 7, art. 86 (promulgated and entered into force on August 24, 1994). Rep. in A. Blaustein \& G. Flanz, eds., Constitutions of the Countries of the World, vol. 1 (New York: Oceana Publications Inc., 1995). Ibid., art. 86. See also art. 43.

$97 \quad$ N.R. Nicotra, supra note 93; J.G. Castañeda, Utopia Unarmed: The Latin American Left After the Cold War (New York: Alfred A. Knopf, 1993) at 385 (calling for more autonomous institutions such as the ombudsman). 
resolution of disputes that is free of charge - in countries where the vast majority of the public do not have the financial and other resources to access the litigation system and where the judicial system itself may be politicized, corrupt or slow.

It is crucial, however, that these offices have effective independence from the executive, that they be treated not just as façades by the executive branch to mask a lack of any real response to maladministration and human rights infringements, and that other appropriate means of support, such as adequate funding, are provided. In this light, some of the new offices have been criticized as being relatively ineffective: by looking, for example, at the reluctance of the executive branch to implement the recommendations of the office, ${ }^{98}$ underfunding of the institution and the absence of jurisdiction over certain sensitive areas of government. ${ }^{99}$

\section{GOVERNMENT IN-HOUSE COMPLAINT MECHANISMS}

Some government departments and agencies have created in-house complaint mechanisms, sometimes called "ombudsmen," which:

provide protection similar to that of executive ombudsmen insofar as their independence is not guaranteed by their status; basically, they are dispute-settlement mechanisms designed to help public authorities improve their policies and administrative practices as well as the services they provide. These internal government department and agency mechanisms have sometimes been created by officialdom in the hope of minimizing its contacts with the official ombudsman, who is viewed as "a stranger in the house. ${ }^{m 100}$

Similarly, crown or state corporations may have ombudsman offices to deal with internal complaints and/or complaints from their public clientele (e.g. the CBC ombudsman). It is in this area that there is the greatest risk of public misconception of the status and role of the complaint-handling mechanism when the name "ombudsman" is used.

\section{E. PRIVATE SECTOR COMPLAINT MECHANISMS/OMBUDSMAN OFFICES}

One form of private sector ombudsman is the corporate ombudsman. These offices are created by individual corporations to settle complaints against them, although the mandate of each mechanism differs from corporation to corporation. ${ }^{101}$ These complaint mechanisms are found in newspapers and other types of companies. The

E.g. the Mexican National Commission of Human Rights (federal and state levels) has been criticized in R.M. Sánchez, "Mexico's Governmental Human Rights Commissions: An Ineffective Response to Widespread Human Rights Violations" (1994) 25 St Mary's L.J. 1041; Amnesty International, Report 1994 (New York: Amnesty International U.S.A., 1994). But contra J. Madrazo, "New Policies on Human Rights in Mexico: The National Commission for Human Rights 1988-1993" (1994) 12 The Ombudsman Journal 19. See also K. Sikkink, "Human rights, principled issue-networks, and sovereignty in Latin America" (1993) 47 Int'l Org. 411 at 432-35. 
university ombudsman office phenomenon may be classified as a variant of the private sector ombudsman institution. Another form of private sector ombudsman is the ombudsman for an entire commercial sector or profession, created as a self-regulating monitor. Thus, for example, there are banking and insurance ombudsman offices. ${ }^{102}$

Like the government in-house mechanism, the private sector ombudsman typically is created and appointed by the management body of the individual company or by the self-regulatory body of the profession or commercial sector, again with the result that such an ombudsman is not truly independent. However, such a mechanism does attempt to meet the needs of consumers who have no choice in contemporary life but to use these "necessary quality of life services"103 and who require some form of dispute resolution mechanism that has a certain amount of objectivity.

\section{F. EMERGENCE OF THE OMBUDSMAN CONCEPT IN THE INTERNATIONAL SYSTEM}

\section{The European Union Ombudsman}

The European Union (EU) obtained its present configuration through the entry into force of the Maastricht Treaty (Treaty on European Union) on November 1, 1993. ${ }^{104}$ On January 1, 1995 the European Union increased from twelve to fifteen member states. ${ }^{105}$ The European Union has evolved out of the European Communities, with the currently-termed European Community (EC) standing as a core element of the Union. ${ }^{106}$ The legal status of the EU is the subject of debate - the EC has often been considered a supranational legal entity that is sui generis, but there are arguments on the potential federal, the intergovernmental and other characteristics of the evolving EU entity. ${ }^{107}$

E.g. the United Kingdom has a number of these private sector ombudsman offices established by statute or private initiative. See Directory of Ombudsmen (London: British and Irish Ombudsman Association, March 1995).

Robertson, supra note 77 at 6.

7 February 1992, 31 I.L.M. 247.

The member states are France, Germany, Belgium, the Netherlands, Luxembourg, Italy, Great Britain, Ireland, Denmark, Greece, Spain, Portugal, Austria, Sweden and Finland. The latter three states joined effective January 1, 1995. A referendum in Norway in the autumn of 1994 rejected EU membership.

The European Economic Community (Treaty of Rome), the European Coal and Steel Community, and Euratom were the original Communities. After mergers and expansion, the Maastricht Treaty inter alia amended the Treaty of Rome and renamed it the Treaty Establishing the European Community. See e.g. R. Corbett, The Treaty of Maastricht: From Conception to Ratification: A Comprehensive Reference Guide (Harlow, U.K.: Longman, 1993); D. Medhurst, A Brief and Practical Guide to EC Law, 2d ed. (Oxford: Blackwell Scientific Publications, 1994). The core institutions of the EU are the Commission, the Council, the Court of Justice and the European Parliament. There are various other institutions and sub-bodies.

See e.g. P. Raworth, "Too Little, Too Late? Maastricht and the Goal of a European Federation" (1994) 32 Archiv des Völkerrechts 24; R. Harmsen, "The Puzzle of Constitutional Assymetry: Recent Canadian and European Debates" (1995) 2 Review of Constitutional Studies 305. 
The EU increases European integration, inter alia, by establishing an economic union moving towards monetary union, creating Union citizenship and envisaging further integration in the future. ${ }^{108}$ The Maastricht Treaty continues the evolution of the EU institutions and, in addition, creates a European Union Ombudsman. ${ }^{109}$ Articles 8d and 138e of Title II of the Maastricht Treaty establish the office and its jurisdictional scope. ${ }^{110}$ Article 8d states that "Every citizen of the Union may apply to the Ombudsman established in accordance with Article 138e." "I Article 138e(1) states that:

The European Parliament shall appoint an Ombudsman empowered to receive complaints from any citizen of the Union or any natural or legal person residing or having its registered office in a Member State concerning instances of maladministration in the activities of the Community institutions or bodies, with the exception of the Court of Justice and the Court of First Instance acting in their judicial role....

Article $138 \mathrm{e}(1)$ further empowers the EU Ombudsman to conduct inquiries on the basis of complaints or on his own motion, to refer established cases of maladministration to the institution concerned and to report to that institution, the European Parliament and the complainant. ${ }^{12}$

Also, Article 138e ensures the considerable independence of the European Ombudsman by providing for her appointment after each European Parliament election for the duration of Parliament's term, granting only limited grounds for dismissal and requiring that the Ombudsman be completely independent in the performance of her duties. ${ }^{113}$

Although EU law is made and administered in a process that is different from that in a domestic parliamentary democracy and the European Parliament is not equivalent to a national parliament in function, the role and jurisdiction of the European Ombudsman is modelled very closely on the national government ombudsman

Maastricht Treaty, supra note 104, Title I (Common Provisions) arts. A \& B.

See R. Gregory, The European Ombudsman: Context and Comment (Reading: Reading Centre for Ombudsman Studies, 1995); R. Gosalbo Bono, "Maastricht et les citoyens: le Médiateur Européen" (Oct.-Dec. 1992) 64 Revue française d'administration publique 639.

Maastricht Treaty, supra note 104, Title II (Provisions Amending the Treaty Establishing the European Economic Community With a View to Establishing the European Community), art. G, arts. $8 \mathrm{~d}$ and $138 \mathrm{e}$.

Article 8(1) establishes citizenship of the Union and states that "[e]very person holding the nationality of a Member State shall be a citizen of the Union." See also Declaration on Nationality of a Member State, Final Act of the Conference in the Maastricht Treaty, ibid, which includes the following: "the question whether an individual possesses the nationality of a Member State shall be settled solely by reference to the national law of the Member State concerned." (ibid. at 365). Maastricht Treaty, ibid. art. 138e(1) also requires the Ombudsman to report annually to the European Parliament on the outcome of his inquiries.

Ibid., art. 138e(2)-(3). E.g. the Ombudsman may be dismissed by the Court of Justice at the request of the European Parliament if the officeholder is no longer fulfilling the conditions required for the performance of office or if guilty of serious misconduct. Also, the European Parliament, in conjunction with other EU institutions, has the task of establishing the regulations and general conditions to govern the functioning of the European Ombudsman. 
institution: with the mandate to inquire into and investigate allegations of maladministration, report and publicize its activities, but with no power to make binding decisions. Effectively, it has a jurisdiction that is even wider than the domestic model since it does have the authority to examine complaints of maladministration against the law-making bodies of the EU - only the judicial activities of the court system of the EU are excluded.

The European Ombudsman appointment procedure was started in 1994 but deadlocked when two of six candidates made it to a second round of voting in the petitions committee of the Parliament. ${ }^{14}$ On July 12, 1995, the European Parliament elected Jacob Söderman, the Parliamentary Ombudsman of Finland, as the first European Ombudsman. ${ }^{115}$

2. In-House Complaint Mechanisms and Ombudsman-like Offices in International Organizations

International (i.e. intergovernmental) organizations proliferate in the modern international system and range from the United Nations (UN), with almost global membership and multiple purposes, to regional or subject-specific international organizations. An international organization is created by member countries pursuant to a multilateral treaty that contains the objectives and powers of the organization. ${ }^{116}$ The organization operates in and is governed by international law, and there is a separation in law between the organization and its individual member states. ${ }^{117}$ An international organization will typically have a number of organs and some form of secretariat that employs international civil servants to administer the daily activities of the organization.

Some of these international organizations have established in-house complaint mechanisms. These mechanisms are purely internal to the international organization and usually only cover complaints by the civil servants of the international organization against the administrative arm of the organization concerning employment-related matters.

For example, international organizations and UN bodies such as the World Bank (International Bank for Reconstruction and Development), the International Finance Corporation, the International Monetary Fund, the World Health Organization and UNICEF have established "ombudsman" offices as employer-employee alternative dispute resolution (ADR) mechanisms. They are internal mechanisms designed to deal with staff complaints as an alternative, or in addition, to the formal administrative procedures and tribunals of these organizations.

114 "European Union Democrats at work" The Economist (20 May 1995) 11.

I1s Letter from M. Oosting to International Ombudsman Institute (13 July 1995).

116 See I. Brownlie, Principles of Public International Law, 4th ed. (Oxford: Clarendon Press, 1990) at $680-93$.

117 Ibid. 
The United Nations has recently created an Office of Internal Oversight Services to assist the UN Secretary-General in the fulfilment of his internal oversight responsibilities covering UN staff and resources. ${ }^{118}$ Again, it is an internal complaints mechanism whereby an Under-Secretary-General for Oversight Services is appointed by the Secretary-General (following consultations with $\mathrm{UN}$ member states and approved by the General Assembly) who has the duty to monitor, audit, inspect and evaluate programmes, investigate reports of violations of UN regulations, rules, etc. and make recommendations and reports thereon to the Secretary-General. ${ }^{119}$ Also, the SecretaryGeneral has made internal proposals concerning the creation of "ombudsman panels" which would act as a form of ADR for staff complaints, ${ }^{120}$ similar to those in existence in other international organizations. These are some steps in the direction of attempting to improve the administration of the UN, but they are certainly not a true ombudsman for the United Nations, a form of office that is increasingly being called for in light of the huge bureaucracy of the UN and its associated administrative problems. ${ }^{121}$

There is also some movement toward hearing external complaints against international organizational governance with the establishment of an Inspection Panel for the World Bank and International Development Association (IDA), operative in September $1994{ }^{122}$ Although the panellists will be appointed by the Executive Directors of the Bank (on the nomination of the Bank's President), the Panel is given the power to investigate complaints lodged by groups of persons in the country where a Bank or IDA-financed project is situated who "complain of a violation of the Bank's [operational] policies and procedures ... [and] who believe that as a result of the Bank's violation their rights or interests have been, or are likely to be adversely affected in a direct and material way." ${ }^{123}$ The Panel is to investigate complaints, decide whether there has been a breach of the pertinent policies and procedures, and then make recommendations to the Executive Directors on which complaints should be investigated. ${ }^{124}$ The Executive Directors decide whether a complaint will be investigated by the Panel and, if so investigated, make the final decision. Both the work of the Panel and the follow-up decision of the Executive Directors will be published. Thus, the Inspection Panel has only trace elements of an executive ombudsman - in appointment and limited powers of recommendation and reporting with the Executive Directors retaining the ultimate decision-making authority in a particular case.

UNGA Res. 48/218B, UN Doc. A/RES/48/218B (12 August 1994).

lbid.

"Major Reform of UN Internal Justice System Would Create Arbitration Board and Ombudsman Panels" International Documents Review (19 June 1995) 3.

See e.g. E. Childers \& B. Urquhart, Renewing the United Nations System (Uppsala: Dag Hammarskjöld Foundation, 1994) at 111.

D.D. Bradlow, "International Organizations and Private Complaints: The Case of the World Bank Inspection Panel" (1994) 34 Va. J. Int'l Law 553; IBRD \& IDA, "Inspection Panel Operating Procedures, Including Executive Directors' Resolution and Explanatory Memorandum of the General Counsel" (1995) 34 I.L.M. 503.

IBRD \& IDA, ibid. at s. 4(a).

See IBRD \& IDA, "Explanatory Memorandum," ibid. at 534, stating that the Panel's "function does not include making recommendations on the adequacy or suitability of existing policies and procedures." 


\section{CONCLUSION}

An ombudsman is able to contribute to the resolution of citizen-government disputes by being:

a willing listener, able to hear both what is said and what is not said;

a vigorous investigator;

a careful weigher of facts;

a skilful presenter of facts and the conclusions which can be drawn from them; and

a crafter of solutions and a master persuader in order to obtain their acceptance. ${ }^{125}$

In this way, an ombudsman performs an important role by providing a form of alternative dispute resolution. This approach to dispute resolution is found in all ombudsman institutions, whether the office is the traditional ombudsman or a variation on the ombudsman model. 